\title{
Losses in milk production and quality due to milk somatic cell count and heat stress of Holsteins cows in temperate climate
}

\section{Perdas na produção e qualidade do leite devido contagem de células somáticas no leite e estresse térmico de vacas da raça Holandesa em clima temperado}

\author{
Agostinho Ludovico $^{1 *}$; Vinicius Buffon Maion²; Dalton Evert Bronkhorst ${ }^{3}$; \\ Fabíola de Almeida Cristine Rego Grecco ${ }^{4}$; Luiz Fernando Coelho da Cunha \\ Filho $^{4}$; Ivone Yurika Mizubuti; ${ }^{5}$ Kelly Molin de Almeida ${ }^{6}$; \\ Marilucia dos Santos Ludovico ${ }^{7}$; Elsa Helena Walter de Santana ${ }^{1}$
}

\begin{abstract}
The aims of present study were to evaluate the effects of milk somatic cell count (SCC) and heat stress on yield and milk composition of cows in a herd for commercial production in a temperate region during the period 2008-2012. Data from the monthly milk test-day records of $161 \pm 9$ Holstein, totaling 9,650 milkings, were provided by the Association of Holstein Cattle Breeders of Parana State, and analyzed by descriptive analysis, correlation, analysis of variance, and regression analysis. The average daily milk yield was $31.78 \mathrm{~kg} / \mathrm{cow}$, which decreased to $29.31 \%$ when the somatic cell score (SCS) was 9 , and to $11 \%$ when the Equivalent Temperature Index (ETI) was 32 or above. Lactose content decreased from SCS 0 until 9 and fat content decreased from SCS 1 until 9, totaling decrease 7.88 and 9.23\%, respectively, when the SCS was 9. An opposite effect was observed for the protein content, which increased by $3.6 \%$ at SCS 8 , when compared to SCS 0 . Losses were observed in the daily total solids production from the SCS 0, totaling 30.64\% at SCS 9.The increase in ETI to 32 or above reduced all milk constituents as much as $3.42 \%$, except protein. These results, combined with the losses in milk yield at that ETI level, led to a decrease of up to $12.74 \%$ of milk solids. It is concluded that since losses in milk quality and yield resulting from SCC and ETI are significant, actions to prevent infection in the mammary gland and to provide a comfortable environment for dairy cattle are needed even in temperate regions.
\end{abstract}

Key words: Equivalent temperature index, climate, milk composition, mastitis, heat stress

\footnotetext{
Profs. Drs., Titulares do Mestrado em Ciência e Tecnologia do Leite e Derivados, Universidade Norte do Paraná, UNOPAR, Londrina, PR, Brasil. E-mail: agostinho@rocketmail.com; elsahws@hotmail.com

2 Médico Veterinário, Discente do Mestrado em Saúde e Produção de Ruminantes, UNOPAR, Londrina, PR, Brasil. E-mail: maionvet@hotmail.com

3 Discente do Curso de Medicina Veterinária, UNOPAR, Londrina, PR, Brasil. E-mail: daltonbronkhorst@hotmail.com

4 Profs. Drs. Titulares, Mestrado em Saúde e Produção de Ruminantes, Universidade Norte do Paraná, UNOPAR, Londrina, PR, Brasil. E-mail: fabiolaregogrecco@gmail.com; luiz.cunha@unopar.br

5 Prof Titular, Universidade Estadual de Londrina, UEL, Londrina, PR, Brasil. E-mail: mizubuti@uel.br

6 Médica Veterinária, Mestrado em Ciência e Tecnologia do Leite e Derivados, UNOPAR, Londrina, PR, Brasil. E-mail: kellym. almeida@hotmail.com

7 Bióloga, Dr ${ }^{\mathrm{a}}$ em Microbiologia, Londrina, PR, Brasil. E-mail: mludovico@yahoo.com

* Author for corresondence
} 


\section{Resumo}

O objetivo deste estudo foi avaliar a influencia da contagem de células somáticas (CCS) no leite e o estresse térmico sobre a produção e composição do leite de vacas de um rebanho de produção comercial em região de clima temperado, durante o período de 2008 a 2012. Os dados do dia de controle leiteiro de $161 \pm 9$ vacas Holandesas, totalizando 9650 ordenhas, foram fornecidos pela Associação Paranaense de Criadores de Bovinos da Raça Holandesa e analisados através de estatística descritiva, correlação, análise de variância e regressão. A produção média diária de leite foi de $31,78 \mathrm{~kg} / \mathrm{vaca}$, com diminuição de 29,31\% quando o escore de contagem de células somáticas (ECS) foi 9 e até $11 \%$ quando o Índice de Temperatura Equivalente (ITE) foi 32 ou maior. Os teores de lactose decresceram a partir do ECS 0 até 9 e de gordura a partir de ECS 1 até 9 , totalizando diminuição de 7,88 e 9,23\%, respectivamente, quando o ECCS foi 9. Um efeito inverso foi observado em relação ao teor de proteína, o qual aumentou 3,6\% com ECS 8, comparado com o ECS 0 . A produção diária de sólidos totais iniciou perdas a partir do ECS 0 e totalizou perdas de 30,64\% quando este foi 9 . O aumento do ITE até 32 ou mais diminuiu a concentração de todos os componentes do leite, exceto de proteína, em valores de até $3,42 \%$ da concentração. Estes efeitos, somados a diminuição na produção diária de leite com este nível de ITE, totalizaram perdas de até $12,74 \%$ na produção de sólidos totais. Conclui-se que as perdas de produção e qualidade de leite com o aumento da CCS e ITE são significativas e podem justificar a adoção de medidas para prevenir infecções na glândula mamária e conforto de vacas leiteiras, mesmo em região de clima temperado.

Palavras-chave: Índice de temperatura equivalente, clima, composição do leite, mastite, estresse térmico

\section{Introduction}

Seeking to increase milk production efficiency, many studies have attempted to identify sources of variation in milk yield and composition (TEIXEIRA et al., 2003). Among these mastitis and factors affecting animals' comfort, such as temperature stand out, both which can result in quantitative and qualitative losses in milk production (BERNABUCCI et al., 2010; HAGNESTAMNIELSEN et al., 2009).

Mastitis is a mammary gland infection accompanied by increased somatic cell count (SCC) in milk (MÜLLER, 2000), which can occur in a clinical or subclinical form, the latter being more common. The somatic cells in milk almost entirely consist of white blood cells and a few sloughing epithelial cells. The leukocytes in normal milk consist of up to $11 \%$ neutrophils and $6888 \%$ macrophage, both being phagocytic cells; 20 to $40 \%$ lymphocytes that produce immunoglobulins, and zero to $7 \%$ sloughing ephtielial cells (LEE et al., 1980).

Mammary gland infection is the main cause of high SCC in milk (DOHOO; MEEK, 1982). Normal geometric mean counts of 29,000 cells $\mathrm{mL}^{-1}$ were observed by Harmon (2001) in 4,213 uninfected mammary quarters. More recently, Pilla et al. (2012) found $19,620 \pm 2,500$ cells $\mathrm{mL}^{-1}$ in 96 uninfected mammary quarters. Currently, it is assumed that the threshold SCC of 100,000 (DVG, 2002) or 200,000 (HARMON., 2001; SORDILLO et al., 1997) cells $\mathrm{mL}^{-1}$ indicates mammary gland infection.

In Brazil, Paula et al. (2004) and Ribas (2013) found 486,810 $\pm 401,550$ and 553,000 $\pm 545,000$ cells $\mathrm{mL}^{-1}$ in 257,540 and $1,995,034$ milk samples collected in bulk tanks in the periods 1999-2001 and 2005-2012, respectively.

Some authors have reported that the SCC markedly affects milk production and composition. Philpot (2002) concluded that for every 100,000 cells $\mathrm{mL}^{-1}$ above the basal level of 200,000 cells $\mathrm{mL}^{-1}$, a loss of $2.5 \%$ is observed in milk production. Coldebella et al (2004) found losses of 0.238 and $0.868 \mathrm{~kg}$ milk in primiparous and multiparous cows, respectively, for each $\log$ of 17,000 cells $\mathrm{mL}^{-1}$.

Higher SCC leads to changes in the concentrations of lactose, fat and protein in milk. According to Auldist (2000), these changes may be 
due to the damage of the blood-milk barrier, with lactose efflux and influx of blood proteins to milk, and lower synthesis capacity due to lesions in the glandular epithelium.

Global warming forecasts (IPCC, 2007) combined with the selection of animals for increased productivity (SHOOK, 2006) have led to increasing concern about losses from heat stress in dairy cattle production. Heat stress decreases production of dairy cows, especially those of high productivity, because the amount of heat generated in metabolism is proportional to production. Normally, the upper limit temperature of the thermoneutral zone for dairy cattle well adapted to heat is 25 to $26^{\circ} \mathrm{C}$ (BERMAN et al., 1985), but some researchers found milk losses from even lowers temperature (ANDRÉ et al., 2011).

Difficulty to dissipate body heat increases maintenance requirements, decreases feed intake, rumination, nutrient absorption, and changes of production or response to somatotropin, insulinlike growth factor, thyroxine, insulin and prolactin (WEST, 2003). These changes result in increased susceptibility to infections, lower milk production, and changes in milk composition (BERNABUCCI et al., 2010, 2014). Milk production decreased by $33 \%$ in the second week when the daily temperature rose from 18 to $29.4-37.8^{\circ} \mathrm{C}$ and relative humidity was $20 \%$ (SHWARTZ et al., 2009).

Given the above, this study aimed to investigate the effects of somatic cell count and heat stress on milk yield and quality for Holstein cows in the temperate climate of southern Brazil.

\section{Material and Methods}

The data used in this study were provided from a commercial dairy farm in the city of Arapoti PR, with geographic coordinates latitude $24^{\circ} 09^{\prime} 28$ "S and longitude 49 49'36" W, with A temperate climate (Cfb), according the Köppen's climate classification (KÖPPEN, 1938).

The present data refers to the milking of $161 \pm 9$ cows a day ${ }^{-1}$ of a total of 468 Holstein cows from the milk test-day recording performed by the Milk
Quality Laboratory of Dairy Herd Analysis Service (PARLPR) of the Paraná State Association of Holstein Bovine Breeders (APCBRH), in the city of Curitiba, from January 2008 to December 2012.

Cows were kept in complete confinement in free-stall facilities, with side eaves of $3 \mathrm{~m}$, rooves of fiber cement tiles, rubber mattresses and fans that were turned on when room temperature reached $20^{\circ} \mathrm{C}$. In the period from 2008 to 2010 , all cows received recombinant bovine somatotropin (bST) every 14 days, from 90 days after calving until 30 days prior to the next calving. The cows were fed ad libitum a total mixed ration twice a day, and were milked three times a day ${ }^{-1}$.

Milk production was determined by weight and composition by sampleS from the three daily milkings of each cow. Samples were placed in 70 $\mathrm{mL}$ plastic containers with Bronopol ${ }^{\circledR}$ preservative (2-bromo-2-nitropropane-1,3-diol) (HORST, 2008, 2010), and sent to the Milk Quality Laboratory of APCBRH for determination of milk composition.

Fat, protein, lactose and total solids content were determined by infrared absorption in the automated equipment Bentley 2000® (Bentley Instruments Inc.), and somatic cell count (SCC) was determined by flow cytometry in an electronic counter, the Somacount $500 \AA$ (Bentley Instruments, Inc.). The non-fat solids content was determined by the difference between total solids and fat contents.

To ensure better accuracy of information, data with more than two and a half standard deviations above and below the mean protein, fat, lactose and total solids content were excluded. The correction of milk production to $4 \%$ fat was made using the equation LCG $4 \%=0.4 \mathrm{x}(\mathrm{kg}$ milk $)+15 \mathrm{x}(\mathrm{kg}$ fat $)$, according to NRC (2001).

Diets were formulated to meet the nutritional requirements of cows using the Cornell Net Carbohydrate Model and Protein System (CNCPS) (FOX et al., 2004) (Table 1). The concentrates represented on average, 54, 48, and $34 \%$ of the total dry matter of diets of high, medium and low production level, respectively. To avoid acidosis and to optimize rumen fermentation, monensin 
(B18), buffering (Bicox supplement) and, in some periods, live yeast (Saccharoyces cerevisiae) were added to diets.

To evaluate the effects of climate on milk yield, the Equivalent Temperature Index (ETI) developed by Baeta et al. (1987) was used, which considers temperature, relative humidity, and wind speed ( $\mathrm{m}$ $\left.\mathrm{sec}^{-1}\right)$ as the following model: $\mathrm{ETI}=27.88-0.456 \mathrm{~T}$ $+0.010754 \mathrm{~T}^{2}-0.4905 \mathrm{U}+0.00088 \mathrm{U}^{2}+1.150 \mathrm{~V}-$ $0.12644 \mathrm{~V}^{2}+0.019876 \mathrm{TU}-0.046313 \mathrm{TV}$, where $T$ is the maximum monthly average temperature in dry- bulb, $U$ is the relative humidity, and $V$ is the wind speed. Climatic data were collected by the ABC Foundation, a Meteorological Station in Arapoti, $4.77 \mathrm{~km}$ away from the farm, and the ETI values were coded by the authors as $1=$ normal (up to 27), $2=$ caution ( 27 to 32$)$, and $3=$ extreme caution ( 32 to 38$)$.

To obtain the normal distribution of SCC data, it was transformed to a logarithmic scale in somatic cell score (SCS) according to the procedure developed by Shook (1993): SCS $=\log 2(\mathrm{CCS} / 100)+3$.

Table 1. Mean, minimum (min) and maximum $(\mathbf{m a x})$ daily milk production, physicochemical composition and ingredients of diets of Holstein cows from different production groups.

\begin{tabular}{|c|c|c|c|c|c|c|c|c|c|}
\hline \multirow[b]{2}{*}{ PARAMETERS } & \multicolumn{3}{|c|}{ High production } & \multicolumn{3}{|c|}{ Medium production } & \multicolumn{3}{|c|}{ Low production } \\
\hline & MEAN & $\max$ & $\min$ & MEAN & $\max$ & $\min$ & MEAN & $\max$ & $\min$ \\
\hline Production, $\mathrm{kg}$ milk day ${ }^{-1}$ & 35.88 & 48.00 & 30,00 & 27.00 & 38.00 & 21.00 & 16.56 & 27.00 & 12.00 \\
\hline \multicolumn{10}{|c|}{ Physicochemical composition of diets (\% DM) } \\
\hline Dry matter, $\% \mathrm{AF}^{1}$ & 48.84 & 54.00 & 43.20 & 46.46 & 53.80 & 40.60 & 43.17 & 48.80 & 36.10 \\
\hline Crude protein & 16.05 & 16.70 & 15.30 & 15.03 & 16.00 & 14.00 & 13.36 & 14.10 & 12.70 \\
\hline RUP $^{2}$ & 4.99 & 5.38 & 4.71 & 4.62 & 5.12 & 4.26 & 4.16 & 4.46 & 3.68 \\
\hline Ether extract & 4.10 & 4.60 & 2.90 & 3.84 & 4.50 & 2.90 & 2.93 & 3.30 & 2.60 \\
\hline $\mathrm{NDF}^{3}$ & 35.28 & 40.90 & 29.50 & 37.47 & 44.00 & 30.60 & 39.91 & 52.30 & 32.70 \\
\hline $\mathrm{ADF}^{4}$ & 19.56 & 21.40 & 16.60 & 20.86 & 23.40 & 17.20 & 21.57 & 28.80 & 18.20 \\
\hline $\mathrm{eNDF}^{5}$ & 22.08 & 27.30 & 17.30 & 24.22 & 29.90 & 18.30 & 26.53 & 40.70 & 20.30 \\
\hline Starch & 26.09 & 28.90 & 23.30 & 25.85 & 29.40 & 21.80 & 25.58 & 30.40 & 14.80 \\
\hline $\mathrm{NEL}^{6}$ & 1.64 & 1.75 & 1.50 & 1.62 & 1.74 & 1.47 & 1.56 & 1.64 & 1.35 \\
\hline Calcium & 0.88 & 1.03 & 0.76 & 0.81 & 0.98 & 0.67 & 0.76 & 1.00 & 0.57 \\
\hline Phosphorus & 0.47 & 0.52 & 0.44 & 0.45 & 0.50 & 0.41 & 0.44 & 0.49 & 0.41 \\
\hline \multicolumn{10}{|c|}{ Ingredient composition of diets ( $\mathrm{kg}$ as feed $\operatorname{cow}^{-1}$ day $\left.^{-1}\right)^{9}$} \\
\hline Corn silage & 29.80 & 42.00 & 15.00 & 28.53 & 39.00 & 15.00 & 25.70 & 39.00 & 10.00 \\
\hline Sorghum silage & 10.00 & 10.00 & - & 8.00 & 10.00 & - & 10.00 & 10.00 & - \\
\hline Wheat silage & 9.50 & 11.00 & - & 10.25 & 11.00 & - & 12.00 & 12.00 & - \\
\hline Oat silage & 6.75 & 8.00 & - & 8.50 & 12.00 & - & 16.00 & 25.00 & - \\
\hline Hay grass & 0.71 & 1.00 & - & 0.67 & 1.00 & - & 0.90 & 2.00 & - \\
\hline Soybean meal & 2.15 & 3.30 & 1,20 & 1.73 & 2.50 & 0.90 & 1.28 & 2.50 & 0.60 \\
\hline Whole cottonseed & 1.92 & 2.50 & - & 1.55 & 2.00 & - & - & - & - \\
\hline Feed mix B $18^{7}$ & 8.60 & 10.50 & 7,50 & 6.50 & 8.50 & 5.00 & 4.26 & 5.00 & 3.50 \\
\hline Mineral supplement & 0.16 & 0.20 & 0,12 & 0.15 & 0.20 & 0.13 & 0.15 & 0.20 & 0.10 \\
\hline BICOX supplement ${ }^{8}$ & 0.28 & 0.30 & 0,22 & 0.19 & 0.25 & 0.13 & 0.15 & 0.15 & - \\
\hline Soaps of fatty acids & 0.23 & 0.30 & - & 0.15 & 0.20 & - & - & - & - \\
\hline Live yeast & 0.01 & 0.01 & - & 0.01 & 0.01 & - & 0.01 & 0.01 & - \\
\hline Dry citrus pulp & 1.77 & 2.30 & - & 1.50 & 2.00 & - & 1.10 & 1.20 & - \\
\hline Ryegrass silage & 9.00 & 9.00 & - & 11.00 & 11.00 & - & - & - & - \\
\hline Soybean hulls & 1.75 & 2.00 & - & 1.75 & 2.00 & - & 1.00 & 1.00 & - \\
\hline Daily intake, $\mathrm{kg}$ of $\mathrm{AF}$ & 46.48 & 48.27 & 43.16 & 42.68 & 47.18 & 37.50 & 36.94 & 41.00 & 34.15 \\
\hline
\end{tabular}

${ }^{1}$ AF: as feed; ${ }^{2}$ RUP: rumen undegradable protein; ${ }^{3}$ NDF: neutral detergent fiber; ${ }^{4}$ ADF: acid detergent fiber; ${ }^{5}$ NDF: effective neutral detergent fiber; ${ }^{6} \mathrm{NEL}$ : net energy of lactation; ${ }^{7}$ Composition: DM: 89.65\%; CP: 18.00\%; EE: 2.38\%; CF: 5.63\%; ADF: 5.34\%; Ash: 1.31\%; Total digestible nutrients: 68.45\%; NEL: $1.66 \mathrm{Mcal} \mathrm{kg}^{-1}$; Lysine: $0.65 \%$; Methionine: $0.27 \%$; Choline: 913.61 mg kg-1; Biotin: 2.500 .00 mcg kg-1 ; Ca: 1.31\%; P: 0.48\%; Mg: 0.48\%; S: 0.14\%; Na: 0.45\%; Mn: 62.5 ppm; Zn: 137.50 ppm; Cu: 31.25 ppm; Co: 0.63 ppm; I: 1.75 ppm; Se: 0.75 ppm; F: 1.48 ppm; Vit A: 10,000 UI/kg; Vit D3: 3,000 UI/kg; Vit E: 55.5 UI/kg; Monensin: $30.00 \mathrm{ppm} ;{ }^{8}$ Composition kg-1 $\mathrm{Mg}: 87.50 \mathrm{~g}$; Na: $145.00 \mathrm{~g} ;{ }^{9}$ Medium refer to the weight when the ingredient has been offered; no minimum amount means the absence of the ingredient in the diet for a period. 
The lactation period was coded according to the milk test-day recording performed monthly. The first milk test-day recording occurred on average on the 27 th day of lactation.

Data were analyzed using Statistica for Windows 8.0 (STATSOFT, 2011), by descriptive analysis, correlation, analysis of variance, and regression analysis. The effects of SCS on contents of milk components were determined by least square regression analysis using the General Regression Model, according to the following scheme: Yijklmn $=\mu+\mathrm{YEA} i+\mathrm{LAC} j+\mathrm{TDN} k+\mathrm{ETI} l+\mathrm{PROD} m+$ $\mathrm{SCS} n+$ eijklmn

where: Yijkl = content of milk component for each SCS; $\mu=$ overall average; YEA $i=$ fixed effect of the year $i(i=2008, \ldots, 2012) ; \mathrm{LAC} j=$ fixed effect of lactation number $j(j=1, \ldots, 9)$; TDN $k=$ fixed effect of the test-day number on lactation $k$ $(k=1, \ldots, 17)$; ETI $l$ : fixed effect of ETI $l(l=1,2$, 3); PROD $m$ : fixed effect of milk yield $m(m=1,5$; $\ldots 82,5)$; SCS $n$ : linear effect of somatic cell count within each score $n(n=1, \ldots, 9)$ and eijklmn $=$ random error associated with each observation. To determine the effect of SCS on both milk yield and components yield, the fixed effect of milk yield was removed from the model.

The effects of ETI on milk yield and on its components were determined using the General Linear Model, considering the random effects of ETI using a design as previously described, but replacing SCS by ETI and vice versa, and the means were compared by Tukey's test at $1 \%$ significance.

\section{Results and Discussion}

The cows were aged $55.77 \pm 23.63$ months on average, with a lactation number of $2.60 \pm 1.64$, and $6.55 \pm 3.93$ test-day recordings in the lactation, and $83.2 \%$ of the data were from up to $10^{\text {th }}$ test-day recording in the lactation (292 days in milk).

The highest milk yield was obtained in the third lactation $\left(33.47 \mathrm{~kg} \mathrm{cow}^{-1}\right.$ day $\left.^{-1}\right)$ and the in the second milking recording (38.19 kg cow ${ }^{-1}$ day $\left.^{-1}\right)$, which occurred on average at day 54 of lactation. The milk yield exceeded the national average and the state of Parana's average, which is 1,382 and 2,404 $\mathrm{kg} \mathrm{cow}^{-1}$ $\mathrm{yr}^{-1}$, respectively (IBGE, 2011), and was similar to the 9,900 cow $^{-1} \mathrm{yr}^{-1}$ average obtained in the USA (USDA, 2014) (Table 2).

The average milk composition (Table 2) was similar to those found by other authors. Ribas (2013) investigated 1,950,034 milk samples collected in bulk tanks in Parana state, and found $4.40 \pm 0.23 \%$ lactose, $3.74 \pm 0.69 \%$ fat, $3.22 \pm 0.27 \%$ protein, and $12.29 \pm 0.85 \%$ total solids. In Minas Gerais state, Teixeira et al. (2003) studied 102,098 individual samples from Holstein cows from 1999 to 2001 and found $4.66 \pm 0.33 \%$ lactose, $3.57 \pm 0.75 \%$ fat, $3.14 \pm 0.38 \%$ protein, and $12.16 \pm 1.05 \%$ total solids. These results are similar to those found in the present study, and demonstrate a higher variability of fat concentration when compared to protein and lactose. The minimum contents required by Brazilian law (BRASIL, 2011) are 3.0\% fat, 2.9\% protein, and $8.4 \%$ total solids.

The somatic cell counts showed high variability, with mean values above the limit of 400,000 cells $\mathrm{mL}^{-1}$ tolerated in New Zealand and Australia, and 500,000 cells $\mathrm{mL}^{-1}$ in Canada, but less than 750,000 cells $\mathrm{mL}^{-1}$ tolerated in the USA (SCHUTZ, 2011). In Brazil, the maximum limit established is 480,000 cells $\mathrm{mL}^{-1}$ (BRASIL, 2011).

Among the possible sources of variation of milk production, the highest positive correlation of this variable was found with test-day number in lactation, year, ETI and SCS. Fat and protein contents were negatively correlated with milk production and positively correlated with test-day number (Table 3). All sources of variation reported had significant affects $(\mathrm{P}<0.01)$ on milk yield and composition. Cunha et al. (2008) also observed negative correlations ( $\mathrm{P}<0.0001$ ) between milk yield and fat $(-0.29)$, protein $(-0.34)$, and SCS $(-0.18)$. 
Table 2. Composition and daily milk production on the milk recording of 468 Holsteins cows during the period 2008$2012\left(161 \pm 9\right.$ cows milked day $\left.{ }^{-1}\right)$.

\begin{tabular}{|c|c|c|c|c|c|}
\hline Parameters & $\mathrm{n}$ & Mean & Minimum & Maximum & SD \\
\hline \multicolumn{6}{|l|}{ Production $\left(\mathrm{kg} \mathrm{cow}^{-1}\right.$ day $\left.^{-1}\right)$} \\
\hline Milk & 9650 & 31.78 & 1.50 & 82.50 & 10.68 \\
\hline Milk corrected to $4 \%$ fat & 9477 & 28.97 & 1.47 & 80.62 & 9.24 \\
\hline Cumulative production on milking day & 9567 & 6913.75 & 47.49 & 34491.35 & 4682.80 \\
\hline Predicted production on 305 days & 9199 & 9430.18 & 1925.97 & 16006.23 & 2146.09 \\
\hline Predicted production at adult age & 9199 & 10486.82 & 2407.47 & 18402.46 & 2339.79 \\
\hline Fat & 9477 & 1.08 & 0.06 & 3.50 & 0.36 \\
\hline Protein & 9321 & 1.01 & 0.09 & 2.31 & 0.30 \\
\hline Lactose & 9485 & 1.47 & 0.08 & 3.56 & 0.50 \\
\hline Total solids & 9531 & 3.85 & 0.20 & 9.50 & 1.21 \\
\hline Non-fat solids & 9450 & 2.77 & 0.14 & 6.59 & 0.89 \\
\hline \multicolumn{6}{|l|}{ Milk composition (\%) } \\
\hline Fat & 9477 & 3.45 & 1.69 & 5.26 & 0.63 \\
\hline Protein & 9321 & 3.23 & 2.60 & 4.21 & 0.33 \\
\hline Lactose & 9485 & 4.55 & 3.70 & 5.21 & 0.24 \\
\hline Total solids & 9531 & 12.16 & 9.56 & 14.79 & 0.90 \\
\hline Non-fat solids & 9450 & 8.71 & 6.54 & 10.22 & 0.43 \\
\hline $\mathrm{SCC}, \mathrm{x} 1000$ cells $/ \mathrm{mL}^{1}$ & 9639 & 637.53 & 1 & 11256 & 1254.19 \\
\hline SCS & 9650 & 3.46 & 0 & 9 & 2.23 \\
\hline Fat : protein ratio & 9185 & 1.07 & 0.48 & 1.97 & 0.18 \\
\hline
\end{tabular}

${ }^{1}$ Somatic cell count; ${ }^{2}$ Somatic cell score.

Table 3. Significant Pearson linear correlation $(\mathrm{p}<0.05)$ for the sources of variation in productivity $\left(\mathrm{kg} \mathrm{cow}^{-1}\right.$ day $\left.^{-1}\right)$ and concentration of constituents $\left(\mathrm{kg} \mathrm{cow}^{-1} \mathrm{day}^{-1}\right)$ of 468 milking Holstein cows from 2008 to 2012 ( $\left.\mathrm{n}=9,560\right)$.

\begin{tabular}{|c|c|c|c|c|c|c|}
\hline & Lactation $^{1}$ & Control $^{2}$ & $\mathrm{SCS}^{3}$ & Year & ETI $^{4}$ & Milk $^{5}$ \\
\hline Milk $\left(\mathrm{kg} \mathrm{cow}^{-1}\right.$ day $\left.^{-1}\right)$ & 0.07 & -0.44 & -0.25 & 0.14 & -0.16 & 1.00 \\
\hline Fat $(\%)$ & -0.04 & 0.16 & - & -0.06 & -0.07 & -0.31 \\
\hline Protein $(\%)$ & -0.02 & 0.55 & 0.31 & 0.14 & - & -0.54 \\
\hline Lactose $(\%)$ & -0.43 & -0.26 & -0.49 & -0.05 & -0.05 & 0.31 \\
\hline Total solids $(\%)$ & -0.18 & 0.26 & -0.03 & -0.07 & -0.08 & -0.36 \\
\hline Fat $\left(\mathrm{kg} \mathrm{cow}^{-1}\right.$ day $\left.^{-1}\right)$ & 0.03 & -0.33 & -0.26 & 0.26 & -0.20 & 0.83 \\
\hline Protein $\left(\mathrm{kg} \mathrm{cow}^{-1}\right.$ day $\left.^{-1}\right)$ & 0.05 & -0.33 & -0.20 & 0.20 & -0.18 & 0.96 \\
\hline Lactose $\left(\mathrm{kg} \mathrm{cow}^{-1}\right.$ day $\left.^{-1}\right)$ & - & -0.45 & -0.31 & 0.15 & -0.16 & 0.99 \\
\hline Total solids $\left(\mathrm{kg} \mathrm{cow}^{-1}\right.$ day $\left.^{-1}\right)$ & 0.04 & -0.41 & -0.28 & 0.26 & -0.19 & 0.98 \\
\hline
\end{tabular}

${ }^{1}$ order of lactation; ${ }^{2}$ number of milk test-day on lactation; ${ }^{3}$ somatic cells score; ${ }^{4}$ equivalent temperature index; ${ }^{5}$ milk production (kg/cow/day).

Climate (ETI) showed a higher correlation with both milk production and its constituents, and a lower correlation with the concentration of the constituents. The SCS was highly correlated with lactose (negative), and protein (positive), which was not observed for the fat content. Bansal et al. (2005) observed a correlation of -0.56 between the lactose concentration and SCC, regardless of the presence of mammary gland infections.

When analyzing the SCS number in relation to the test-day number (Figure 1), it was found that although SCS decreased until the second testday number (53 days), it increased linearly by the following test-day numbers, while the milk yield showed the opposite trend. 
Figure 1. Least squares means (points) and $95 \%$ confidence intervals (bars) of milk production $\left(\mathrm{kg} \mathrm{cow}^{-1}\right.$ day $\left.^{-1}\right)$ and somatic cell score in milk, according to the number of the milk test-day on lactation of Holstein cows, from 2008 to $2012(\mathrm{n}=9.560)$.

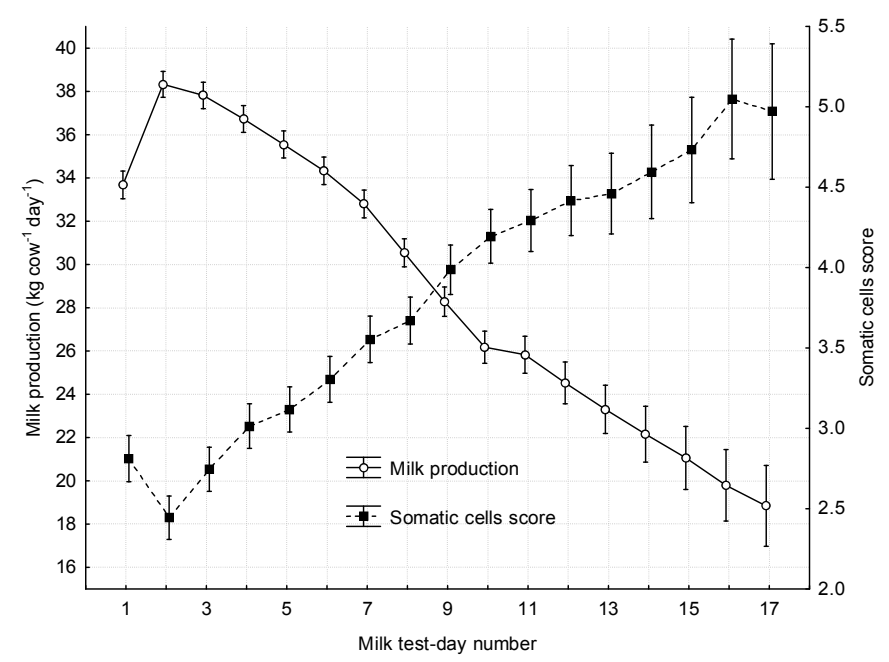

The SCC is usually high in colostrum and gradually decreases in early lactation (O'ROURKE; BLOWEY, 2004). Schepers et al. (1997) analyzed data from 22,467 mammary quarters of 544 cows in seven high production herds, and found SCC decreased until 40-80 days after calving. Rampino et al. (2006) evaluated the SCC in uninfected mammary quarters in heifers during the first 24 days after birth, and found a geometric mean of 671 cells $\mathrm{mL}^{-1}$ at birth, decreasing to $47 \mathrm{~mL}^{-1}$ cells after 24 days. According to Koeck et al. (2012), the threshold proposed by Canadian Holstein as mastitis indicator are 500,000 cells $\mathrm{mL}^{-1}$ from 5 to 10 days of lactation.

Schalm et al. (1971) attributed the SCC in colostrum to excessive sloughing of epithelial cells in a small volume of milk in a gland that is restarting functional activity after a dormant period. However, recent studies have found that from two weeks before calving, the somatic cells in the uninfected mammary gland consist mainly of phagocytic cells (MILLER et al., 1990; SMITH; TODHUNTER, 1982). Gomes et al. (2011) studied the cells in colostrum of 171 uninfected mammary quarters of 53 cows, milked up to 12 hours after parturition and found 68 to $69.5 \%$ monocytes and epithelial cells. These authors reported difficulties in differentiating epithelial cells and macrophages, which may explain the disagreements among researchers about the type of cells.

From the second test-day in lactation, the increasing SCC in milk may be due to either the lower milk yield with a consequent increase of cell concentration (O'ROURKE; BLOWEY, 2004), or a physiological response to infection of the parenchyma mammary gland (HAND et al,. 2012; SCHEPERS et al., 1997). Although SCS over 200,000 cells $\mathrm{mL}^{-1}$ is generally considered a subclinical mastitis indicator (PANTOJA et al., 2009), McDougall (2012) has suggested the limit of 120,000 cells $\mathrm{mL}^{-1}$ in primiparous females and 150,000 cells $\mathrm{mL}^{-1}$ in multiparous females in New Zealand.

Table 4 shows the SCC, milk yield, and production losses for each SCS. According to Linzell and Peaker (1971), the volume of milk produced is a result of the osmotic gradient determined by lactose in the secretory cells. In this study, the highest correlation was observed between SCS and lactose concentration (Table 3), which was negative $(-0.49)$, and is consistent with the decrease in milk production observed with the increase in somatic cells concentration. 
Table 4. Somatic cell score (SCS), somatic cells count (SCC), least square means of milk production, and milk losses with different SCS in milk of Holstein cows from 2008 to 2012.

\begin{tabular}{cccccc}
\hline SCS & $\begin{array}{c}\text { SCC } \\
(\mathrm{x} \mathrm{1000)}\end{array}$ & $\mathbf{N}$ & $\begin{array}{c}\text { Production } \\
\left(\mathrm{kg} \mathrm{cow}^{-1} \mathrm{day}^{-1}\right)\end{array}$ & $\begin{array}{c}\text { Losses } \\
\left(\mathrm{kg} \mathrm{cow}^{-1} \text { day }^{-1}\right)\end{array}$ & $\begin{array}{c}\text { Losses } \\
(\%)\end{array}$ \\
\hline 0 & $1-24$ & 966 & $34.59 \pm 0.29$ & 0.00 & 0.00 \\
1 & $25-49$ & 922 & $34.20 \pm 0.30$ & 0.39 & 1.13 \\
2 & $50-99$ & 1439 & $34.27 \pm 0.24$ & 0.32 & 0.92 \\
3 & $100-199$ & 1636 & $32.65 \pm 0.22$ & 1.94 & 5.61 \\
4 & $200-399$ & 1383 & $31.89 \pm 0.24$ & 2.70 & 7.80 \\
5 & $400-799$ & 1003 & $30.20 \pm 0.29$ & 4.38 & 12.68 \\
6 & $800-1597$ & 786 & $28.89 \pm 0.32$ & 5.70 & 16.48 \\
7 & $1601-3191$ & 554 & $29.22 \pm 0.38$ & 5.37 & 15.53 \\
8 & $3209-6389$ & 346 & $27.37 \pm 0.49$ & 7.21 & 20.85 \\
9 & $6418-11256$ & 98 & $24.45 \pm 0.91$ & 10.14 & 29.31 \\
\hline
\end{tabular}

Lactose is synthesized in the epithelial cells of the mammary parenchyma, and the inflammatory reaction caused by pathogens leads to cell damage in the gland resulting in decreased synthesis in the glandular cells and leakage of lactose from the alveoli into the blood (HARMON, 1994; SHUSTER et al., 1991).

Reports of losses due to increased SCC differ among researchers. Akers and Nickerson (2011) reported increasing losses from 12,500 cells $\mathrm{mL}^{-1}$, totaling $22.94 \%$ of the production, with SCC of 6.4 million cells $\mathrm{mL}^{-1}$ milk. Hagnestam-Nielsen et al. (2009) reported that the losses increase in the stage of lactation, and found losses with 1,000,000 cells $\mathrm{mL}^{-1}$, ranging from 3.8 to $11.2 \%$ of milk yield in primiparous cows, and 5.9 to $23.6 \%$ during 3 to 8 and 33-44 weeks of lactation, respectively.

Hand et al. (2012) studied the effects of SCC on 869,414 milking cows in 2,835 herds in Canada, and observed increasing losses with lactation number and cow productivity. In cows with SCC of 2 million cells $\mathrm{mL}^{-1}$, the milk losses varied from $6.23 \%$ in primiparous low production cows, and were up to $11.58 \%$ in high production cows in third lactation. According to Green et al. (2006), the dilution effect of milk production on SCC can explain the greatest losses found in higher production cows with similar SCC.
Milk with SCS 0 presented a composition similar to that reported by other researchers (EASTRIDGE, 2012; RIBAS, 2013), with an average of $3.44 \pm$ $0.02 \%$ fat, $3.13 \pm 0.01 \%$ protein, $4.65 \% \pm 0.01$ lactose, $12.17 \pm 0.03 \%$ total solids, and $8.73 \pm$ $0.02 \%$ non-fat solids (Figure 2). Several factors can alter milk composition, including physiological factors related to race, age, stage of lactation, and exogenous factors such as climate, nutrition and health, or mastitis, which can be monitored by SCC (BANSAL et al., 2005; FONSECA; SANTOS, 2000; TEIXEIRA et al., 2003).

The higher SCS led to a change in the concentration of various milk constituents (Figure 2). The lactose content, which is the main determinant of milk volume production (LINZELL; PEAKER, 1971) decreased with increasing SCS, totaling decrease of $7.88 \%$ for SCS 9, when compared to SCS 0 . The lower lactose content with the increase in SCC has been reported by other authors (GEARY et al., 2013). The inflammatory reaction caused by pathogens in the mammary gland leads to cellular damage resulting in decreased lactose synthesis and leakage from alveoli to blood due to the increasing permeability of the blood-milk barrier (HARMON, 1994; SHUSTER et al., 1991).

Fat level losses were observed from SCS 1, with a reduction of $9.23 \%$ in SCS 9 . According to 
Azzara and Dimmick (1985), higher SCC leads to a decrease in fat synthesis, due to damage in the secretory epithelium and lipolytic or proteolytic activity of leukocyte enzymes. However, lower milk production can result in higher fat concentration, which may explain the results up until SCS 1, at which point the fat levels decreased.

The protein content increased linearly until SCS 8, totaling 3.60\%, and decreased between SCS 8 and 9. Milk proteins may be either derived from serum (e.g. immunoglobulin, albumins) or synthesized in the mammary gland (e.g. casein, lactalbumin, lactoglobulin). Casein can be reduced by the proteolytic activity of plasmin from the blood or by the decreased synthesis caused by cell injury, but the damage of the blood-milk barrier may increase the serum protein influx into the alveolar (AULDIST et al., 1995; KITCHEN, 1981; NG-KWAI-HANG et al., 1982). This latter mechanism may explain the higher protein concentration with the increase SCS in milk of the present study.

The effects of SCS on lactose, fat, and protein concentrations, combined with a reduction of milk yield (Table 4), resulted in changes proportionally greater of constituents production than those observed only of its concentrations, once a decrease of $28.31 \%$ was observed for lactose, $24.62 \%$ for fat content, and $18.50 \%$ for protein, from SCS 0,1 , and 2, respectively (Figure 2).

Figure 2. Least squares means (points) and $95 \%$ confidence intervals (bars) of milk constituents concentration (\%) and production $\left(\mathrm{kg} \mathrm{cow}^{-1} \mathrm{day}^{-1}\right)$, according to the somatic cells score in Holstein milk $(\mathrm{n}=9.560)$.

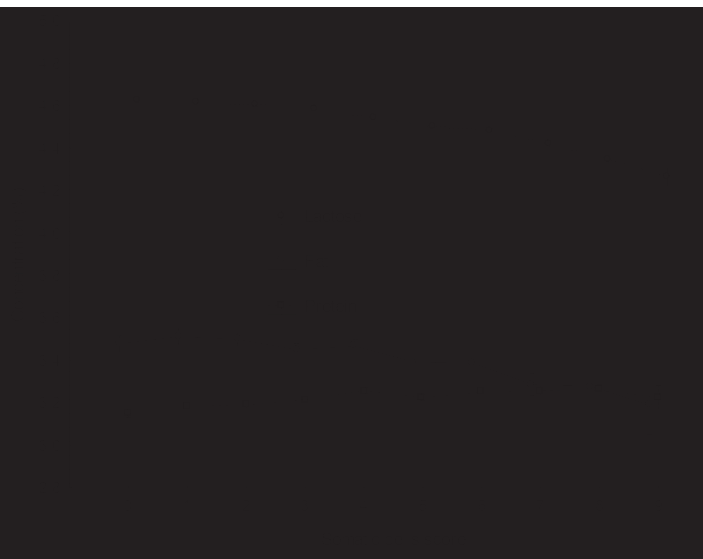

The effects of SCS on lactose, fat, and protein production determined decreased production and concentration of total solids and non-fat solids in milk (Figure 3). The level of total solids decreased by $6.79 \%$ from SCS 1, and the non-fat solids decreased by $5.04 \%$ from the SCS 4 to 9 . However, the production of these constituents began to

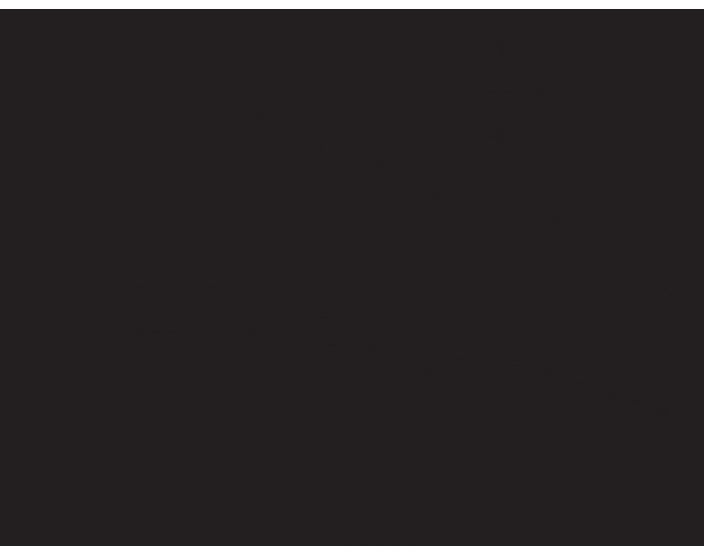

decrease from SCS 0, with total loss of $30.64 \%$ total solids and $30.66 \%$ non-fat solids. The 0.5 percent reduction in total solids can mean loss of up to 1 $\mathrm{kg}$ of milk powder per 200 liters of milk processed. Thus, from SCS 1, milk quality losses can affect both the producer and the industry that remunerates farmers based on weight. 
Figure 3. Least squares means (points) and $95 \%$ confidence intervals (bars) of concentration (\%) and production (kg cow $^{-1}$ day $\left.^{-1}\right)$ of solids and non-fat solids according to the somatic cells score (SCS) in Holstein milk $(\mathrm{n}=9.560)$.
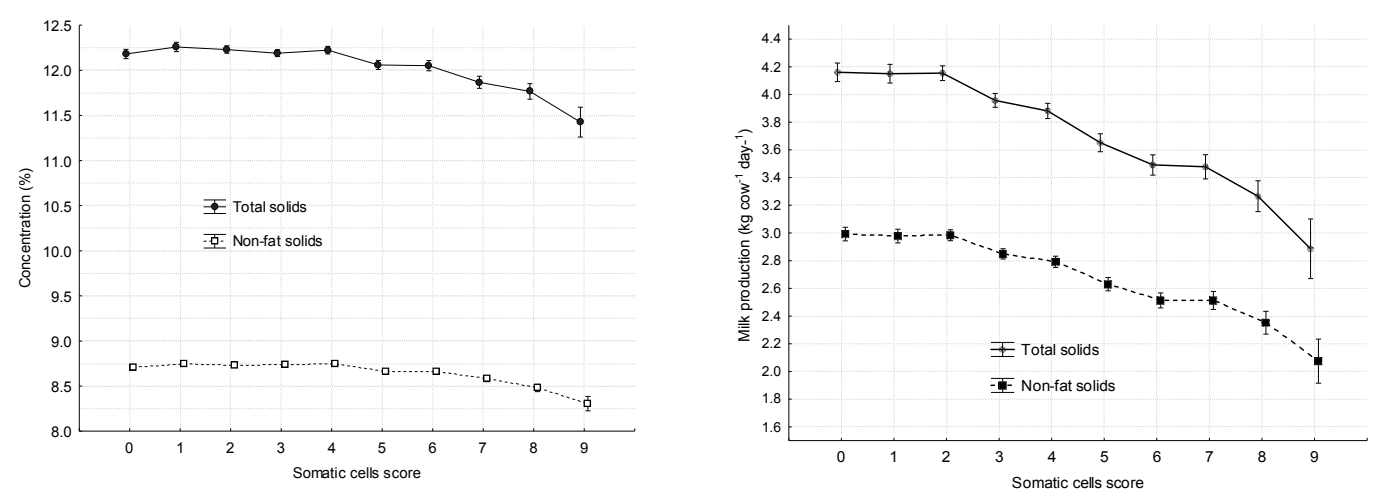

The ETI had significant effects $(\mathrm{P}<0.01)$ on milk yield and composition (Table 5), but no interaction $(\mathrm{P}>0.05)$ was observed between ETI and SCS. A quarter of all time studied, from December to March, the ETI was at the level of "extreme caution" (above 32), and from April to September, the index was always within the level "normal" (up to 27) (Figure 4).

Table 5. Means of production and composition of Holsteins milk, according to the Equivalent Temperature Index, from 2008 to 2012, in municipality of Arapoti - PR.

\begin{tabular}{lcccc}
\hline \multirow{2}{*}{ Variable } & \multicolumn{3}{c}{ Equivalent Temperature Index } & Mean \\
\cline { 2 - 3 } & $\begin{array}{c}\text { Up to 27 } \\
(\mathrm{n}=3718)\end{array}$ & $\begin{array}{c}\mathbf{2 7 - 3 2} \\
(\mathrm{n}=2803)\end{array}$ & $\begin{array}{c}\mathbf{3 2 - 3 8} \\
(\mathrm{n}=2612)\end{array}$ & \\
\hline Milk constituents (\%) & $3.51 \pm 0.64^{\mathrm{a}}$ & $3.41 \pm 0.63^{\mathrm{b}}$ & $3.39 \pm 0.61^{\mathrm{b}}$ & 3.44 \\
Fat & $3.23 \pm 0.33$ & $3.22 \pm 0.32$ & $3.22 \pm 0.33$ & 3.23 \\
Protein & $4.56 \pm 0.24^{\mathrm{a}}$ & $4.55 \pm 0.24^{\mathrm{a}}$ & $4.53 \pm 0.24^{\mathrm{b}}$ & 4.55 \\
Lactose & $12.23 \pm 0.91^{\mathrm{a}}$ & $12.11 \pm 0.91^{\mathrm{b}}$ & $12.06 \pm 0.86^{\mathrm{b}}$ & 12.15 \\
Total solids & $8.72 \pm 0.43^{\mathrm{a}}$ & $8.70 \pm 0.43^{\mathrm{a}}$ & $8.66 \pm 0.42^{\mathrm{b}}$ & 8.70 \\
Non-fat solids & & & & \\
Daily production $\left(\mathrm{kg} \mathrm{cow}^{-1} \mathrm{day}^{-1}\right)$ & $33.73 \pm 10.87^{\mathrm{a}}$ & $31.75 \pm 10.43^{\mathrm{b}}$ & $30.02 \pm 9.95^{\mathrm{c}}$ & 32.06 \\
Milk & $1.17 \pm 0.39^{\mathrm{a}}$ & $1.06 \pm 0.34^{\mathrm{b}}$ & $1.00 \pm 0.27^{\mathrm{c}}$ & 1.09 \\
Fat & $1.08 \pm 0.30^{\mathrm{a}}$ & $1.01 \pm 0.29^{\mathrm{b}}$ & $0.95 \pm 0.27^{\mathrm{c}}$ & 1.02 \\
Protein & $1.56 \pm 0.50^{\mathrm{a}}$ & $1.46 \pm 0.49^{\mathrm{b}}$ & $1.38 \pm 0.46^{\mathrm{c}}$ & 1.48 \\
Lactose & $4.11 \pm 1.23^{\mathrm{a}}$ & $3.83 \pm 1.17^{\mathrm{b}}$ & $3.60 \pm 1.11^{\mathrm{c}}$ & 3.88 \\
Total solids & $2.95 \pm 0.87^{\mathrm{a}}$ & $2.76 \pm 0.85^{\mathrm{b}}$ & $2.60 \pm 0.80^{\mathrm{c}}$ & 2.79 \\
Non-fat solids & & & \\
\hline
\end{tabular}

a,b,c Means with different letters in the same row differ by Tukey's test $(\mathrm{P}<0.01)$ 
Figure 4. Monthly means (points) and 95\% confidence intervals (bars) for Equivalent Temperature Index and daily milk production of Holsteins $(n=9.560)$ from 2008 to 2012, in municipality of Arapoti - PR

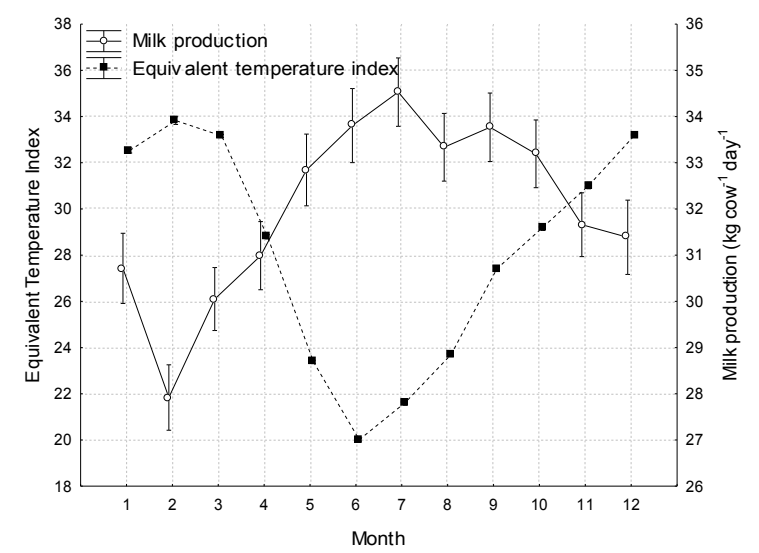

With the exception of protein content, all milk constituents decreased with the increase in ETI values. Fat content showed a greater reduction, which was 3.42\% lower when the ETI was over 32, compared to the ETI until 27 (Table 5). Mean daily milk production decreased by $5.87 \%$ and $11 \%$ when ETI was 27 to 32 and above 32, respectively. These effects combined with the decrease in nutrients concentration with increased ETI from 32 to 38 resulted lower daily production at the following percentages: $11.54 \%$ lactose, $14.53 \%$ fat, $12.04 \%$ protein, $12.41 \%$ total solids, and $11.86 \%$ non-fat solids.

The amount of heat generated in the metabolism of lactating cows is proportional to its productivity, and its dissipation through skin and respiratory evaporation is related to climatic factors such as temperature, relative humidity, and wind speed (KADZERE et al., 2002; WEST, 2003). When these factors limit heat losses and impede comfort, the cow enters a state of thermal stress, which results in lower food consumption, rumination, and absorption of nutrients, higher nutritional requirements, and hormonal changes, which may lead to lower yield and changes in milk composition (BERNABUCCI et al., 2010, 2014).

The productive response to heat stress can be affected by productivity, climate adaptation, parity and stage of lactation, among others (KADZERE et al., 2002; WEST, 2003). Although $25-26^{\circ} \mathrm{C}$ is usually considered as the upper limit temperature of the thermo-neutral zone (BERMAN et al., 1985), Berman (2005) found a decrease of $5^{\circ} \mathrm{C}$ in the temperature limit for the occurrence of heat stress when milk production increased from 35 to $45 \mathrm{~kg} / \mathrm{cow} /$ day. Also, in the Netherlands, André et al. (2011) observed an adverse effect on dairy production when room temperatures rises from 16 to $20^{\circ} \mathrm{C}$.

The specific physiological mechanisms for changes in the synthesis of milk constituents in cows with heat stress are still subject of studies (BAUMGARD; RHOADS, 2013). According to Rhoads et al. (2009), the decrease in food intake, which enables a decrease in heat production in rumen fermentation, explains only about 30 to $50 \%$ decrease in milk yield. Furthermore, the lower efficiency of digestion and intestinal absorption results in reduced nutrients supply for the postabsorptive metabolism (BAUMGARD; RHOADS, 2013; KADZERE et al., 2002).

Endocrine changes markedly modify the postabsorptive metabolism and milk synthesis in cows with heat stress. A decrease in the number of hepatic somatotropin receptor $(\mathrm{GH})$, hepatic production of insulin-like growth factor (IGF-1), and thyroxine 
(T4 and T3), and an increase in prolactin and insulin has been reported. These alterations may cause a reduction in lipolysis, an increase in protein catabolism, gluconeogenesis from amino acids, and preferential use of glucose by peripheral tissues, which results in decreased availability of precursors for the synthesis of milk constituents in the mammary gland (BAUMGARD; RHOADS, 2013; COLLIER; ZIMBELMAN, 2007).

Considering that the losses observed during the test-day occurred throughout the study period, it can be estimated that the ETI resulted in annual losses of 94,560 $\pm 15,400 \mathrm{~L}^{\text {milk year }}{ }^{-1}$ and 11,250 $\pm 1,740$ $\mathrm{kg}$ total solids year-1, both representing $5.2 \pm 0.3 \%$ of milk production.

Hammami et al. (2013) studied data from 230,192 milking cows in Germany, and found production losses from ETI 18. The authors estimated by regression a decrease in daily production of 0.146 $\mathrm{kg}$ milk, $0.012 \mathrm{~kg}$ protein, and $0.022 \mathrm{~kg}$ fat for each ETI unit increase above this value.

The losses observed in this study are low when compared with the $33 \%$ reduction in milk yield in the second week, when the daily temperature rose from 18 to 29.4 to $37.8^{\circ} \mathrm{C}$, and relative humidity of $20 \%$ in a climatic chamber, as reported by Shwartz et al. (2009). These authors also observed a decrease of $7.4 \%$ protein and $3.6 \%$ lactose, while no difference was observed in the fat content. According to the authors, the lower variation in lactose content may be due to its participation in the osmotic regulation of milk.

\section{Conclusion}

An SCC higher than 24,000 cells $\mathrm{mL}^{-1}$ in milk results in losses, which totals $29.31 \%$ in milk production, and $30.64 \%$ in total solids with $6,418,000$ cells $\mathrm{mL}^{-1}$ or more. The qualitative losses totaling $7.88 \%$ lactose, and $9.23 \%$ fat in milk with similar SCC.
Milk production in Holstein cows in temperate climates does not prevent the occurrence of heat stress. Losses due to climate started from ETI $27-$ 32, while ETI values from 32 to 38 led to $11 \%$ losses in milk yield, $14.53 \%$ in fat, $12.04 \%$ in protein and $12.41 \%$ in total solids production.

Losses related to the health of the mammary gland and heat stress observed in the present study are enough to justify an assessment of viability to prevent gland mammary infections and to provide comfortable environment for dairy cattle, even in a climate classified as temperate.

\section{Acknowledgements}

The authors thank Paraná State Association of Holstein Bovine Breeders for granting the milk recording database and the $\mathrm{ABC}$ Foundation for Research and Agricultural Development for providing the meteorological data from the meteorological station of the municipality of Arapoti.

\section{References}

AKERS, M. R.; NICKERSON, S. C. Mastitis and its impact on structure and function in the ruminant mammary gland. Journal of Mammary Gland Biology and Neoplasia, Oklahoma City, v. 16, n. 4, p. 275-289, 2011.

ANDRÉ, G.; ENGEL, B.; BERENTSEN, P. B. M.; VELLINGA, T. V.; OUDE LANSINK, A. G. J. M. Quantifying the effect of heat stress on daily milk yield and monitoring dynamic changes using an adaptive dynamic model. Journal of Dairy Science, Champaign, v. 94, n. 9, p. 4502-4513, 2011.

AULDIST, M. J. Effects of mastitis on raw milk and dairy products. In: PACIFIC CONGRESS ON MILK QUALITY AND MASTITIS CONTROL, 2000, Japan, Proceedings... Japan, Nagano, 2000. p. 191-204.

AULDIST, M. J.; COATS, S.; ROGERS, G. L.; McDOWELL, G. H. Changes in the compositional of milk from healthy and mastitic dairy cows during the lactation cycle. Australian Journal of Experimental Agriculture, Melbourne, v. 35, n. 4, p. 427-436, 1995. 
AZZARA, C. D.; DIMMICK, P. S. Lipoprotein lipase activity of milk from cows with prolonged subclinical mastitis. Journal of Dairy Science, Champaign, v. 68, n. 12, p. 3171-3175, 1985.

BAETA, F. C.; MEADOR, N. F.; SHANKLIN, M. D.; JHONSON, H. D. Equivalent temperature index at temperatures above the thermoneutral for lactating cows. ASAE Paper No. 874015. St. Joseph, MI: American Society of Agricultural Engineers, 1987. 21 p.

BANSAL, B. K.; HAMANN, J.; GRABOWSKI, N.; SINGH, K. B. Variation in the composition of selected milk fraction samples from healthy and mastitis quarters, and its significance for mastitis diagnosis. Journal of Dairy Research, Cambridge, v. 72, n. 2, p. 144-152, 2005.

BAUMGARD, L. H.; RHOADS, R. P. Effects of heat stress on postabsortive metabolism and energetic. Annual Review of Animal Bioscience, Palo Alto, v. 1, n. 1, p. 311337, 2013.

BERMAN, A. Estimates of heat stress relief needs for Holstein dairy cows. Journal of Animal Science, Champaign, v. 83, n. 6, p. 1377-1384, 2005.

BERMAN, A.; FOLMAN, Y.; KAIM, M.; MAMEN, M.; HERZ, Z.; WOLFENSON, D.; ARIELI, D.; GRABER, Y. Upper critical temperatures and forced ventilation effects for high-yielding dairy cows in a subtropical climate. Journal of Dairy Science, Champaign, v. 68, n. 6, p. 1488-1495, 1985.

BERNABUCCI, U.; BIFFANI, S.; BUGGIOTTI, L.; VITALI, A.; LACETERA, N.; NARDONE, A. The effects of heat stress in Italian Holstein dairy cattle. Journal of Dairy Science, Champaign, v. 97, n. 1, p. 471486, 2014.

BERNABUCCI, U.; LACETERA, N.; BAUMGARD, L. H.; RHOADS, R. P.; RONCHI, B.; NARDONE, A. Metabolic and hormonal acclimation to heat stress in domesticated ruminants. Animal, Cambridge, v. 4, n. 7, p. 1167-1183, 2010.

BRASIL. Ministério da Agricultura, Pecuária e Abastecimento. Instrução Normativa 62, de 29 de Dezembro de 2011. Aprova o regulamento técnico de produção, identidade e qualidade do Leite tipo A, o regulamento técnico de identidade e qualidade de Leite Cru refrigerado, o regulamento técnico de identidade e qualidade de Leite pasteurizado e o regulamento técnico da coleta de Leite cru refrigerado e seu transporte a granel. Diário Oficial [da] República Federativa do Brasil, Brasília, Seção 1, 30 dez. 2011. p. 6.

COLDEBElla, A.; MACHADO, P. F.; DEMÉTRIO, C. G. B.; RIBEIRO JUNIOR, P. J.; MEYER, P. M.; CORASSIN, C. H.; CASSOLI, L. D. Contagem de células somáticas e produção de leite em vacas holandesas confinadas. Revista Brasileira de Zootecnia, Viçosa, MG, v. 33, n. 3, p. 623-634, 2004.

COLLIER, R. J.; ZIMBELMAN, R. B. Heat stress effects on cattle: what we know and what we don't know. In: ANNUAL SOUTHWEST NUTRITION \& MANAGEMENT CONFERENCE, 22., 2007, Tempe. Proceedings... Tempe: University of Arizona, 2007. p. 76-83.

CUNHA, R. P. L.; MOLINA, L. R.; CARVALHO, A. U.; FACURY FILHO, E. J.; FERREIRA, P. M.; GENTILINI, M. B. Mastite subclínica e relação da contagem de células somáticas com número de lactações, produção e composição química do leite em vacas da raça Holandesa. Arquivo Brasileiro de Medicina Veterinária e Zootecnia, Belo Horizonte, v. 60, n. 1, p. 283-288, 2008.

DOHOO, I. R.; MEEK, A. H. Somatic cell counts in bovine milk. Canadian Veterinary Journal, Ottawa, v. 23, n. 4, p. 119-125, 1982.

EASTRIDGE, M. L. Variation in milk fat of fresh cows. In: TRI-STATE DAIRY NUTRITION CONFERENCE, 2012, USA. Proceedings... USA, Ft. Wayne, 2012 . p. 5965.

FONSECA, L. F. L.; SANTOS, M. V. Qualidade do leETI e controle de mastETI. São Paulo: Lemos Editorial, 2000. $176 \mathrm{p}$.

FOX, D. G.; TEDESCHI, L. O.; TYLUTKI, T. P.; RUSSEL, J. B.; VAN AMBURGH, M. E.; CHASE, L. E.; PELL, A. N.; OVERTON, T. R. The Cornell Net Carbohydrate and Protein System model for evaluating herd nutrition and nutrient excretion. Animal Feed Science and Technology, Mason City, v. 112, n. 1/4, p. 29-78, 2004.

GEARY, U.; LOPEZ-VILLALOBOS, N.; O'BRIEN, B.; GARRICK, D. J.; SHALLOO, L. Meta-analysis to investigate relationships between somatic cell count and raw milk composition, Cheddar cheese processing characteristics and cheese composition. Irish Journal of Agricultural and Food Research, Carlow, v. 52, n. 2, p. 119-133, 2013.

GERMAN VETERINARY SOCIETY - DVG. Leitlinien zur Bekämpfung der Mastitis des Rindes als Bestandsproblem. Giessen: DVG, 2002.

GOMES, V.; MADUREIRA, K. M.; DELLA LIBERA, A. M. M. P.; BLAGITZ, M. G.; ALAVES, M.; BAPTISTELlA, F.; BENESI, F. J. Dinâmica da celularidade do colostro de vacas da raça Holandesa no pós-parto imediato. Arquivo Brasileiro de Medicina Veterinária e Zootecnia, Belo Horizonte, v. 63, n. 5, p. 1047-1053, 2011. 
GREEN, L. E.; SCHUKKEN, Y. H.; GREEN, M. J. On distinguishing cause and consequence: do high somatic cell counts lead tolower milk yield or does high milk yield lead to lower somatic cell count? Preventive Veterinary Medicine, Amsterdan, v. 76, n. 1, p. 74-89, 2006.

HAGNESTAM-NIELSEN，C.; EMANUELSON，U.; BERGLUND, B.; STRANDBERG, E. Relationship between somatic cell count and milk yield in different stages of lactation. Journal of Dairy Science, Champaign, v. 92, n. 7, p. 3124-3133, 2009.

HAMMAMI, H.; BORMANN, J.; M'HAMDI, N.; MONTALDO, H. H.; GENGLER, N. Evaluation of heat stress effects on production traits and somatic cell score of Holsteins in a temperate environment. Journal of Dairy Science, Champaign, v. 96, n. 3, p. 1844-1855, 2013.

HAND, K. J.; GODKIN, A.; KELTON, D. F. Milk production and somatic cell counts: a cow-level analysis. Journal of Dairy Science, Champaign, v. 95, n. 3, p. 1358-1362, 2012.

HARMON, R. J. Physiology of mastitis and factors affecting somatic cell counts. Journal of Dairy Science, Champaign, v. 77, n. 7, p. 2103-2112, 1994.

HARMON, R. J. Somatic cell count: a primer. In: ANNUAL MEETING NATIONAL MASTITIS COUNCIL, 40., 2001, Reno. Proceedings... Madison: National Mastitis Council, 2001. p. 3-9.

HORST, J. A. Manual de coleta de amostras: componentes e CCS. Curitiba: Programa de Análise de Rebanhos Leiteiros do Paraná, APCBRH, 2010. 16 p.

HORST, J. A.. Manual de operações de campo. Curitiba: Programa de Análise de Rebanhos Leiteiros do Paraná, APCBRH, 2008. $10 \mathrm{p}$.

INSTITUTO BRASILEIRO DE GEOGRAFIA E ESTATÍSTICA - IBGE. Produção pecuária municipal. Rio de Janeiro, 2011. Available at: <http://www.ibge.gov. br/home/estatistica/economia/ppm/2011/default_pdf. shtm>. Accessed: 16 nov. 2012.

INTERGOVERNMENTAL PANEL OF CLIMATE CHANGE -IPCC: Climate change: the physical science basis. In: SOLOMON, S.; QIN, D.; MANNING, M.; CHEN, Z.; MARQUIS, M.; AVERYT, K. B.; TIGNOR, M.; MILLER, H. L. (Ed.). Contribution of working group $i$ to the fourth assessment report of the intergovernmental panel on climate change. Cambridge: Cambridge University Press, 2007. p. 996.

KADZERE, C. T.; MURPHY, M. R.; SILANIKOVE, N.; MALTZ, E. Heat stress in lactating dairy cows: a review. Livestock Production Science, Amsterdam, v. 77, n. 1, p. 59-91, 2002.
KITCHEN, B. J. Reviews of progress of dairy science: milk compositional changes and related diagnostic tests. Journal of Dairy Science, Champaign, v. 48, n. 1, p. 167$188,1981$.

KOECK, A.; MIGLIOR, F.; KELTON, D. F.; SCHENKEL, S. Alternative somatic cell count to improve mastitis resistance in Canadian Holstein. Journal of Dairy Science, Champaign, v. 95, n. 1, p. 432439, 2012.

KÖPPEN, W. Climatologia: con um estúdio de los climas de la tierra. México: Fondo de Cultura Economica, 1938. $478 \mathrm{p}$.

LEE, C. S.; WOODING, F. B. P.; KEMP, P. Identification properties, and differential counts of cell populations using electron microscopy of dry cows secretions, colostrum and milk from normal cows. Journal of Dairy Research, Cambridge, v. 47, n. 1, p. 39-50, 1980.

LINZELL, J. L.; PEAKER, M. Mechanism of milk secretion. Physiological Reviews, New York, v. 51, n. 3, p. 564-597, 1971.

McDOUGALL, S. Managing subclinical mastitis: what's is new? NEW ZEALAND MILK QUALITY CONFERENCE, 2012, New Zealand, Proceedings... New Zealand: [s.n.], 2012. p. 60-76.

MILlER, R. H.; PAAPE, M. J.; PETERS, R. R.; YOUNG, M. D. Total and differential somatic cell counts and N-Acetyl-f3-D-glucosaminidase activity in mammary secretions during dry period. Journal of Dairy Science, Champaign, v. 73, n. 7, p. 1751-1755, 1990.

MÜLLER, E. E. Profilaxia e controle da mastite. In: WORKSHOP SOBRE PRODUÇÃO E QUALIDADE DO LEITE, 2., 2000, Maringá. Anais... Maringá: [s.n.], 2000. p. 10-13.

NATIONAL RESEARCH COUNCIL- NRC. Nutrient. Requirements of dairy cattle. $7^{\text {th }}$ ed. Washington, D.C.: National Academy of Sciences, 2001. 381 p.

NG-KWAI-HANG, F. K.; HAYES, J. F.; MOXLEY, J. E.; MONARDES, H. G. Environmental influences on protein content and composition of bovine milk. Journal of Dairy Science, Champaign, v. 65, n. 10, p. 1993-1998, 1982.

O'ROURKE, D. J.; BLOWEY, R. W. Bulk milk testing and mastitis monitoring. In: ANDREWS, A. H.; BLOWEY, R. W.; BOYD, H.;R. G.; EDDY, R. G. Bovine medicine: diseases and husbandry of cattle. $2^{\text {th }} \mathrm{ed}$. Oxford: Blackwell, 2004. p. 341-35236. 
PANTOJA, J. C. F.; HULlAND, C.; RUEGG, P. L. Dynamics of somatic cell counts and intramammary infections across the dry period. Preventive Veterinary Medicine, Amsterdan, v. 90, n. 1-2, p. 43-54, 2009.

PAULA, M. C.; RIBAS, N. P.; MONARDES, H. G.; ARCE, J. E.; ANDRADE, U. V. C. Contagem de células somáticas em amostras de leite. Revista Brasileira de Zootecnia, Viçosa, MG, v. 35, n. 5, p. 1303-1308, 2004.

PHILPOT, W. N. Qualidade do leite e controle de mastite: passado, presente e futuro. In: CONGRESSO PANAMERICANO DE QUALIDADE DO LEITE E CONTROLE DA MASTITE, 2., 2002, Ribeirão Preto. Anais... Ribeirão Preto: Instituto Fernando Costa, 2002. p. 23-38.

PILLA, R.; SCHWARZ, D.; KONIG, S.; PICCININI, R. Microscopic differential cell counting to identify inflammatory reactions in dairy cow quarter milk samples. Journal of Dairy Science, Champaign, v. 95, n. 8, p. 4410-4420, 2012.

RAMPINO, M. L.; CORREA, M. T.; MEIER, A.; ANDERSON, K. L. Analysis of milk somatic cell counts (SCC) of dairy heifers in early lactation from cherry dairy farm. In: MID-ATLANTIC DAIRY GRAZING CONFERENCE, 6., 2006, Goldsboro, Proceedings... Goldsboro: [s.n.], 2006. Available at: $<$ http://www.cefs. ncsu.edu/publications/dairyconferenceproceedings/ dairyproceedingshome.html . Accessed: 16 nov. 2014.

RIBAS, N. P. Contagem de células somáticas e suas relações com os componentes do leETI em amostras de tanques no estado do Paraná. 2013. Tese (Doutorado em Ciências Veterinárias) - Universidade Federal do Paraná, Curitiba.

RHOADS, M. L.; RHOADS, R. P.; VAN BAALE, M. J.; COLLIER, R. J.; SANDERS, S. R.; WEBER, W. J.; CROOKER, B. A.; BAUMGARD, L. H. Effects of heat stress and plane of nutrition on lactating Holstein cows: I. Production, metabolism, and aspects of circulating somatotropin. Journal of Dairy Science, Champaign, v. 92, n. 5, p. 1986-1997, 2009.

SCHALM, O. W.; CARROL, E. J.; JAIN, N. C. Bovine mastitis. Philadelphia: Lea e Febiger, 1971. 360 p.

SCHEPERS, A. J.; LAM, T. J. G. M.; SCHUKKEN, Y. H.; WILMINK, J. B. M.; HANEKAMP, W. J. A. Estimation of variance components for somatic cell counts to determine thresholds for uninfected quarters. Journal of Dairy Science, Champaign, v. 80, n. 8, p. 1833-1840, 1997.
SCHUTZ, M. M. Changes in standards for milk quality and how they will affect your clients. In: PROCEEDINGS OF TRI-STATE DAIRY NUTRITION CONFERENCE, 2011, Ft. Wayne. Proceedings... Ft. Wayne, 2011. p. 7987. Available at: $<\mathrm{http}: / /$ tristatedairy.org/proceedings. htm>. Accessed: 16 nov. 2014.

SHOOK, G. E. Genetic improvement of mastitis through selection on somatic cell count. Veterinary Clinics of North America- Food Animal Practice, Philadelphia, v. 9, n. 3, p. 563-581, 1993.

Major advances in determining appropriate selection goals. Journal of Dairy Science, Champaign, v. 89, n.4, p. 1349-1361, 2006.

SHUSTER, D. E.; HARMON, R. J.; JACKSON, J. A.; HEMKEN, R. W. Suppression of milk production during endotoxin-induced mastitis. Journal of Dairy Science, Champaign, v. 74, n. 11, p. 3763-3774, 1991.

SHWARTZ, G.; RHOADS, M. L.; VANBAALE, M. J.; RHOADS, R. P.; BAUMGARD, L. H. Effects of a supplemental yeast culture on heat stressed lactating Holstein cows. Journal of Dairy Science, Champaign, v. 92, n. 3, p. 935-942, 2009.

SMITH, K. L.; TODHUNTER, D. A. The physiology of mammary gland during the dry period and the relationship to infection. In: ANNUAL MEETING OF NATIONAL MASTITIS COUNCIL, 1982, Louisville. Proceedings... Louisville: National Mastitis Council, 1982. p. 87.

SORDILLO, L. M.; SHAFER-WEAVER, K.; ROSA, D. Imunobiology of mammary gland. Journal of Dairy Science, Champaign, v. 80, n. 8, p. 1851-1865, 1997.

STATSOFT, Inc. STATISTICA (data analysis software system), version 10. Tulsa: Statsoft, Inc., 2011.

TEIXEIRA, N. M.; FREITAS, A. F.; BARRA, R. B. Influência de fatores de meio ambiente na variação mensal da composição e contagem de células somáticas do leETI em rebanhos no Estado de Minas Gerais. Arquivo Brasileiro de Medicina Veterinária e Zootecnia, Belo Horizonte, v. 55, n. 4, p. 491-499, 2003.

UNITED STATES DEPARTMENT OF AGRICULTURE - USDA. Milk production USDA. National Agricultural Statistics Service, jan. 2014. Available at: $<$ http://www. nass.usda.gov/Publications/Todays_Reports/reports/ mkpr0114.pdf $>$. Accessed at: 1 maio 2014.

WEST, J. W. Effects of heat-stress on production in dairy cattle. Journal of Dairy Science, Champaign, v. 86, n. 6, p. 2131-2144, 2003. 
